\title{
Pan-pan Girls: Humiliating Liberation in Postwar Japanese Literature
}

\author{
Rumi Sakamoto, University of Auckland
}

\section{Introduction}

The relationship between gender and militarism has become an important subject for feminists globally in recent years. In particular, numerous studies exist on the sexual violence of women that seems to go hand-in-hand with militarism and war. The 'comfort women' of the Japanese military during the Pacific War is a case in point; as the victims of military, colonial, and gender violence, the comfort women seem to embody the harrowing brutality that is mobilised when hierarchical colonial relations are expressed through another such hierarchical relation - that of gender. Less discussed in this context, however, is the case of the so-called pan-pan girls. This is the derogatory term for the street prostitutes who served the soldiers of the Allied forces, mostly from the USA, during the occupation of Japan from 1945 to 1952, and who sometimes became the local girlfriends of GIs. ${ }^{1}$ Extending our consideration of military apparatuses and gender hierarchies to the pan-pan girls, I hope to add to the existing work on comfort women and the sexual exploitation of women by the military in postwar Japan. In particular, I draw attention to how 'pan-pan girls' resist being reduced to pure signs of 'victim' or 'sacrifice,' given that they embody complex articulations of interracial desire, material ambition and opportunism, as well as victimhood.

In order to explore that embodiment, this article examines a number of postwar literary representations of the pan-pan girls. Rather than directly addressing the historical reality of pan-pan girls during the occupation period, I prefer to look at how they have been

\footnotetext{
${ }^{1}$ The etymology of the word 'pan-pan' is unclear. John Dower suggests that its origin may have been a US imitation of a South Pacific island word for easily available women (Dower 1999: 132).
} 
represented in post-occupation Japan, particularly in literature. This is because the rich literary representation of the ambivalence and complexity of the pan-pan girls' experiences allows us to consider aspects of the occupation of Japan and postoccupation Japanese history in relation to such sociocultural forces as national rehabilitation, economic prosperity, and ultimately, Americanisation. Since the intersection of military occupation and gender is at once a cultural, historical and political phenomenon, it is important to understand the complex patterns of meaning production around gender and occupation beyond the mere collation of historical facts.

This approach is required in the Japanese case because the meanings, understandings and interpretations generated by a specific event or issue continue to influence the national psyche long after the political and historical event itself is over. Indeed, cultural production relating to the pan-pan girls continued after the women disappeared from the Japanese social landscape. By deciphering the structures of meaning constructed around the image of the pan-pan girls since the end of the physical occupation, I hope to address not just the direct sexual violence of 65 years ago, but also the textual violence that ensures the trauma recurs in the present. As recent work on trauma and historical memory shows us, it is not only individuals but also groups of people that suffer trauma from historical events such as war and colonial domination. And, as in individual cases, collective trauma necessitates some processing and working though of the experience, for example, by compulsively repeating the stories of the trauma or reformulating it into a collective memory. ${ }^{2}$ The following discussion, then, is an attempt to read literary texts as a site of such repetition compulsion, understood as a working through and an acting out of the collective trauma of the occupation. ${ }^{3}$

There are a few studies of how the pan-pan girls have been represented, including Mike Molasky's pioneering work in English (Molasky 1999), as well as studies in Japanese (Chasono 2002; Arai 2007; Yoshimi 2007). Molasky and Chasono focus on social and journalistic representations from the contemporary period, whereas Arai looks at Japanese Christians' attitudes towards prostitution during the immediate postwar period, demonstrating how representations of the pan-pan girls emerged from the intersection of

\footnotetext{
${ }^{2}$ See, for example, Caruth (1996), Neal (1998), LaCapra (2002), and Kaplan (2005).

${ }^{3}$ A special issue on war and trauma in positions (2008) contains a number of articles that consider trauma in the Asian context. In particular, Marilyne Ivy (2008) and Thomas Lammare (2008) address how traumatic memories or war and devastation are repeated in contemporary Japanese manga and anime respectively.
} 
religious and gender metaphors. Yoshimi Shunya, citing Dower and Molasky, analyses the 'Americanism' of the pan-pan girls in literature and society as a 'subversive threat to national masculinity' (2007: 109). No study systematically examines the literary representations of the pan-pan girls after the occupation period.

The following analysis of the representations of the pan-pan girls in postwar Japanese literature begins by discussing the role of these women in occupation history. Typical portrayals of the pan-pan girls in literature are then examined, with a focus on how panpan girls function as a narrative trope for remembering the occupation. I discuss three popular novels: Murakami Ryu's Kagirinaku tōmei ni chikai burū (Almost Transparent Blue, 1976); Shimada Masahiko’s Taihai shimai (Decadent Sisters, 2005); and Kumagai Tatsuya's Itsuka X-hashi de (Someday on the X Bridge, 2008). In these novels I identify three distinctive patterns of representation and thus demonstrate how the panpan girls function as a trope for remembering the occupation as a 'humiliating' liberation. Kagirinaku tōmei ni chikai burū was published in 1976, when political tension around US-Japanese relations was still palpable, if not intense. Set in a town hosting a US military base in the 1970s, the novel evokes the memories of the occupation. Taihai shimai and Itsuka X-hashi de, on the other hand, were published in 2005 and 2008 respectively. By then the Americanisation of Japanese everyday life, as well as the Japanese state's commitment to its political alignment with the USA, had become an established fact, with memories of the war and occupation receding into a distant past. Significantly, however, this was when post-1990s revisionist history and xenophobic nationalism established themselves within public discourse, thereby challenging the dominant narrative of postwar Japanese history as a seamless prosperity achieved under US protection. This revisionism provided a context for a rereading of postwar history with an emphasis on Japan's subjection to the USA - a possible context for the allusions particularly in the latter two novels to the 'humiliating' liberation brought by the occupation. Finally, I discuss briefly the relevance of cultural imaginaries embedded in literature for broader politico-historical concerns with gender and militarism in contemporary Japanese history.

\section{Some history: RAA and pan-pan girls}

Immediately after the Second World War, the Japanese government established the Recreation and Amusement Association (RAA), a euphemism for brothels arranged for 
US servicemen. Because of the widespread sexual violence committed by Japanese soldiers during the war, the Japanese government assumed that a similar situation would occur when the occupation started in Japan (Yoshimi 2007: 104). Three days after Japan's unconditional surrender to the Allied Forces, the Home Ministry sent a secret memorandum to the police chiefs, ordering them to establish seiteki ian shisetsu (comfort institutions) that would handle the sexual demands of the incoming soldiers (Lie 1997: 257). Through private traders and public appeal, several thousand womenmostly poverty-stricken and without the economic means to survive-were employed to become Japanese comfort women (Tanaka 2001: 147). In a short time occupying soldiers were queuing at their doors. By providing sexual services for those soldiers, the comfort women were expected to protect the 'purity' and 'chastity' of regular Japanese women from rape and other acts of violence by the 'sex-hungry' occupation troops. As Koikari points out, ultimately, RAA was designed as a 'defence of the nation' by maintaining the racial and sexual purity of the 'respectable' Japanese in the face of the 'foreign invasion' (1999: 321). The irony of the system was that poverty-stricken middle class women often ended up as prostitutes, thus blurring the line between 'respectable women' and 'not-so-respectable women' (Aruga 2005: 86). In this situation, the pan-pan girls emerged where the interests of the Occupying Force and the Japanese government met.

When the RAA was closed down in 1946 due to US government concerns over widespread VD amongst its occupying forces, many of the women who lost their jobs became private and illegal prostitutes - the pan-pan girls. The occupation authorities tried to regulate the so-called fraternisation between GIs and these women. A 1946 edition of Time magazine, for example, reports that a GI was banned from taking Japanese girls to dinner or a movie, and from offering them US cigarettes, chewing gum or chocolate bars. Indeed, Time noted that 'any public display of affection may subject a GI to arrest' ('Japan: Prostitutes' Union' 1946). Still, despite the official line, GIs did fraternise with the pan-pan girls, and public displays of intimacy, and the exchange of cigarettes, chewing gum and chocolate, were commonplace in occupied Japan.

\section{Pan-pan girls in literature: an icon of the occupation period}

With their red lipstick, Lucky Strike cigarettes, nylon stockings and high-heeled shoes, and often holding on the arms of tall, uniformed GIs, the pan-pan girls became an icon 
of the occupation, and have been textually reproduced throughout the postwar period. In this section I analyse images and representations of the pan-pan girls in postwar Japanese literature in order to identify how they have functioned as disturbing metaphors for sexual corruption, that is, as agents who contributed to the negative construction in the public Japanese memory of the Allied occupation. While the representations of the pan-pan girls are neither unified nor stable, recognisable patterns, stereotypes, and common codes of representation recur throughout the postwar period. Pan-pan girls have signified eroticism and decadence, as well as sexual freedom and materialism. But they have also appeared as symbols of victimisation, humiliation and national trauma - in particular, the trauma of the defeated nation as experienced by male Japanese citizens. My aim here is to demonstrate that, during the 60-plus years since the end of the Second World War, the highly gendered and sexualised bodies of the pan-pan girls have functioned as a discursively burdened repository for Japanese memories of the occupation. I suggest that certain representations of the pan-pan girls have perpetuated the survival of a simplistic and selective remembering of the occupation as an external corruption, a remembering that has glossed over the historical influence of traditional Japanese patriarchy itself on postwar Japan.

Common to all written and visual representations of pan-pan girls is the focus on their appearance. Even during the occupation, when censorship precluded reference to US GIs in Japan, pan-pan girls were clearly codified with their red lipstick, nail polish, cigarettes, high heels, strong perfume, and provocative dress codes. They are often described as 'women of the night' who wore brightly coloured Western-style dresses, chewed gum and spoke coarsely in 'Panglish. ${ }^{4}$ Such women invariably appear in literary representations as highly sexualised beings. Interestingly, existing photographic images of pan-pan girls tend not to portray them as sexually glamorous. Despite John Dower's comment that the pan-pan girls were the closest thing Japan had to Hollywood movie stars (1999: 137), many of them were more like heavily made-up teenagers.

Yet, it is arguable that the postwar Japanese scholarly and literary imagination has conceived of the pan-pan girls as the hypersexualised, larger-than-life icons per se of occupied Japan itself. A number of historians have mentioned the contemporary envy

\footnotetext{
4 'Panglish' was the postwar colloquial English term for the purportedly elementary, unsophisticated and slang-dominated English that the pan-pan girls used in their delaings with Allied servicemen under the occupation (Dower 1999: 134-35).
} 
for the pan-pan girls and their material possessions. This is evident, for example, in the contemporary comments of primary school children, such as: 'I'd like to be a pan-pan when I grow up. They have beautiful dresses and expensive shoes, and ride in cars-it looks like fun' (Chasono 2002: 94). But this kind of envy and desire rarely exists in the postwar literature. What dominates, instead, is a strong sense of the pity, contempt and general discomfort felt by the other characters around the women. The pan-pan girls' ostentatious looks and possessions certainly stand out from the other characters' shabby clothes, poverty and hunger. But their dresses, cosmetics and bags full of PX (Post Exchange - shops within the US military bases) goods are almost always accompanied by a sense of threat, amorality and disapproval. For example, in Hotta Yoshie's story 'Kumoribi' (Cloudy Day, 2004), a pan-pan girl called Yoko is living a 'plush life' filled with material goods - an 'electronic record player ... two wardrobes ... food in shiny tins' - but she is also characterised as having a 'vulgar mind' and a complete lack of modesty. In one notable scene, for example, she yells to the male protagonist: 'get me the scissors! ... I let the bastard lick me because he was so insistent, and now I cannot get the chewing gum off my [pubic] hair' $(2004: 286){ }^{5}$

In Abe Akira's story 'Sennen' (One Thousand Years, 1980), Reiko, the main character's cousin who has become a pan-pan girl, is described as 'loose' and 'scandalous.' She has an 'arrogant hairstyle with a perm as if threatening her parents,' and wears a 'ring with a ridiculously large blue stone' and a 'gaudy dress.' Although Reiko's family and relatives benefit from her new job in the form of 'PX tins, soaps ... Lucky Strike and Half and Half,' her transformation into a pan-pan girl is a 'taboo' topic no one dares to discuss. The main character, vaguely aware that Reiko is an object of sexual exploitation by 'hairy Yankees,' simply rationalises his lack of sympathy towards her situation by thinking '[unlike another cousin who is a student] that one is a cousin who does not mind this sort of thing' (1980: 72-76). Pan-pan girls are thus constructed as having an unsettling difference from other, 'respectable' women who live within the 'good wife, wise mother' norm.

Generally speaking, the 'pan-pan girls' are not marked with traditionally available feminine gender codes such as shyness, modesty, naivety and loyalty. Instead they are characterised as having flippant manners and vulgar speech, and as rejecting the 'good

\footnotetext{
${ }^{5}$ All translations are the author's own.
} 
wife, wise mother' ideology. They 'sit with their legs wide open like a man' and 'drink in the middle of the day' (Nishino 1954: 390), 'use toilet[s] ... with the glass door more than half open' (Abe 1980: 70-71), make socially unacceptable sexual advances, and tease and challenge men. Their non-reproductive sexuality sets them apart from the normative Japanese gender role of wives and mothers in the novels under discussion. Although it is at least theoretically possible to represent their non-reproductive commercial sex as a resistance against male control of sexuality, all in all, pan-pan sexuality is depicted not as liberating or empowering but as immoral and dangerous, especially when considered in light of how other women are represented in the novels.

For example, in Abe Kazushige's novel Shinsemia (Sin Semillas [Without Seeds]), an influx of pan-pan girls turns a whole town into 'pan-pan town' or an 'obscene sex town' (2006: 223), and culminates in a series of horrendous crimes. The rumour among the town's housewives that one of the pan-pan girls was sleeping with a married Japanese man precipitates a tragic suicide of the accused girl following four days of gruesome assault by the townspeople (2006: 225-32). We can read this episode as a story of the punishment of pan-pan sexuality that threatened the traditional position and status of housewives, who embody normative Japanese femininity. In other stories, too, the panpan girls are located at the very margin of society, constituting the opposite pole of the 'good wife, wise mother.' In the next section, however, I use examples from each text in order to discuss how pan-pan representations are used to inscribe complex and disputed memories of the postwar occupation.

\section{Kagirinaku tōmei ni chikai burū: Japan's subjection to the USA}

Murakami Ryu's 1976 novel, Kagirinaku tōmei ni chikai burū uses a pan-pan woman as a symbol of Japanese humiliation and US domination. By 1976, the narrative of Japan's postwar history had already solidified around the key theme of Japan's democratisation as Americanisation. According to this narrative, the USA cured Japan of fanatic militarism and taught her a lesson of democracy and individual rights. Along with this line, Japanese women's history published in the 1970s typically focused on women's liberation and empowerment; pan-pan girls were either completely ignored or treated as an embarrassing postscript to the grand narrative of women's liberation (see, for 
example, Ito [1974], and Itoya and Ezashi [1977]). ${ }^{6}$ Kagirinaku tōmei ni chikai burū challenges this mainstream perspective by using the metaphor of sexual subjection to problematise the unequal power relations between the USA and Japan. Via a pan-pan image, the narrative (re)inserts the memory of the traumatic occupation into the narrative of democracy and liberation.

The story describes a group of Japanese youths living near a US military base in the 1970s, leading a reckless life filled with drugs and sex. Towards the end of the story, the main character, Ryu, has a flashback from his childhood, when he used to collect the rent from a US doctor living in his aunt's house:

\begin{abstract}
Every time I was there the American doctor showed me the vagina of a Japanese woman who was thin like an ape and very hairy. ... The Japanese woman with heavy make-up showed me between her legs while thrashing about on her back ... the doctor stuck different objects between her scrawny buttocks and made me look at them. She smeared some lipstick on the sheet and glared at me, yelling 'give me a cigar' (in broken English) in a loud voice. The doctor was laughing his head off, with a whiskey bottle in his hand. (Murakami 1978: 142-43)
\end{abstract}

This scene, and in fact much of the novel, is saturated with an intense and painful sense of humiliation stemming from US power and Japanese loss of power. In this particular flashback, Ryu, as a young boy, is metaphorically emasculated, unable to compete with the US doctor who humiliates the pan-pan. ${ }^{7}$ Ryu's loathing and disgust, however, are not directed towards the doctor but towards the pan-pan, whom he calls 'a retarded Japanese woman' (Murakami 1978: 144). He seems powerless in relation to the doctor, who embodies both the occupation and US military power. The 'retarded woman' herself is not in the least disturbed by the violation, seemingly unable to feel the humiliation she 'should' feel from Ryu's perspective - the humiliation Ryu is feeling so desperately, on behalf of her. The image of a pan-pan here functions as a poignant

\footnotetext{
${ }^{6}$ Ito's book on the postwar history of Japanese women refers to the pan-pan girls in the context of an episode where two Japanese female members of the Cinema and Theatrical Workers Union of Japan were arrested because they were mistaken for pan-pan girls. Whilst Ito commends the assertiveness of the women who complained to the authorities about the incident, she does not discuss the plight of the panpan girls themselves (1974: 64). Itoya and Ezashi's study of women's liberation after the war mentions the pan-pan girls only terms of their negative influence on village communities and their young people and children (1977: 116, 118).

${ }^{7}$ Emasculated Japanese male characters are commonly linked to pan-pan girls in the literature. Another example appears in Sakaguchi Ango's short story, 'Machi wa furusato,' where the Japanese male character who befriends a group of pan-pan girls is referred by them as 'brother,' 'uncle' and 'teacher.' $\mathrm{He}$ is also somewhat feminised (variously described as being 'like a prince,' having 'weak eyes,' 'innocent young man' and, on one occasion, 'not a man') and not regarded as a sexual object by the girls (Sakaguchi 1950: 4-5). In the case of Decadent Sisters byShimada Masahiko, the father-the household head - is in prison and absent for much of the story, implying the weakened position of the Japanese male and patriarchy at the time (Shimada 2005: 81-82).
} 
reminder of Japan's subjection and collective trauma, experienced from the subject position of the men of the defeated nation.

What this kind of representation conceals, however, is the complicity between the USA and Japan in the operation of the occupation. The Supreme Commander of the Allied Powers (SCAP) ruled through the existing Japanese government and bureaucracy, and was supported and welcomed by the majority of the Japanese. When the occupation is represented as a one-sided power relationship of domination/subjection, the realities that the occupation was a co-production between Japan and the USA, or in part the outcome of a voluntary choice on the part of Japan, are glossed over. Depicting a pan-pan as a somewhat monstrous and 'retarded' figure, and letting a male character despise her, confirm a certain historical forgetting and displacement at work in these literary texts. The male character is spared from experiencing humiliation directly. Rather, the 'shameful' Japan that welcomes US domination is externalised onto the body of the pan-pan and then rejected by the male, national, subject position.

\section{Taihai shimai: the self-imposed pain of occupation}

Although humiliation and suffering are regularly projected onto the pan-pan representations, the pan-pan girls are rarely depicted as naïve victims of sexual violence under the occupation. I am yet to find a pan-pan girl in Japanese literature who suffers a violent rape by US soldiers. On the contrary, pan-pan girls are often pictured as willing accomplices of their own violation, as women who knowingly participate in the humiliating act of prostitution for the sake of material gain even if they may also be depicted as lacking a sense of self-worth. This again seems to suggest the merit in regarding the occupation as an undertaking managed jointly by both Japan and the USA, however hierarchical the relation between the countries may have been.

A telling scene, for example, appears in Shimada Masahiko's 2005 Taihai shimai. One of the main characters, Kumiko, decides to become a pan-pan after her father is imprisoned as a war criminal for having made war-propaganda films. Although the description of her first experience of intercourse is unromantic, forceful and violent, and on the surface appears to depict a rape, Kumiko is fully aware of her agency in the act, construing her motive for losing her virginity to a US soldier in this manner: 'I want to do something useful for defeated Japan' (Shimada 2005: 101). Her act appears as a selfchosen initiation into pan-pan ranks in exchange for a pair of nylon stockings. As she 
loses consciousness from the pain of the intercourse, she tells herself: 'this is a path everyone has to go down; the virgin Kumiko has just died, and a new Kumiko is born; this is a gift from me to America' (128). The blood-stained sheet under her body is then described as a 'crumpled Rising Sun flag' (129). It is easy to read this rebirth of Kumiko as a gendered metaphor for Japan's painful rebirth as a nation via the occupation, whereby all Japanese walked the same path in order to achieve postwar prosperity. Japan's 'gift to America' was the new Japan, politically subservient to the USA, and accepting the establishment of military bases throughout the country under the Mutual Security Treaty. Old-style national pride may have crumbled, but complying with postwar US hegemony was a self-conscious choice. Japan, like Kumiko, was not simply a naïve victim of the US occupation. The pan-pan girls, who readily sold their bodies in exchange for a pair of stockings or a packet of cigarettes, seem a fitting trope for remembering the occupation as neither a gift nor a curse, but both. Kumiko's choice to become a pan-pan girl cannot be read as simple victimhood; instead it suggests both self-determination and complicity with the occupiers.

While the above scene from Taihai shimai uses a pan-pan girl as a metaphor for Japan's painful complicity with the USA, pan-pan girls in the novel are also depicted as agents of resistance to the US occupation. As Kumiko's pan-pan friend puts it, 'even though Tokyo is occupied by the Americans, we are now going to occupy the Americans' heart and purse' (Shimada 2005: 137). Kumiko understands that they are faced with the choice of "whether to join in the group of "us," the pan-pan girls who declare a body-tobody battle against the occupying soldiers, or remain passively occupied,' and decides that 'since she was not going to get her virginity back, she might as well make the American soldiers pay for it' (137). When it comes to Japanese men, the novel simply states that 'for the men of the defeated nation, proving their loyalty to the victors of the war became a matter of life-or-death' (51), again suggesting male opportunism. The task of resisting the occupation is given to the women, their weapon of choice being commodified sex. Japanese male characters are thus spared from directly engaging with the humiliation of the liberation via occupation as Taihai shimai assigns the job of overcoming the ambivalence of humiliation-liberation to the pan-pan girls. Unlike Kagirinaku tōmei ni chikai burū, where the pan-pan woman bears the humiliation and trauma of occupation on behalf of the male national subject, Taihai shimai accords the role of national subject, at once complicit and resistant, to the pan-pan girls themselves. 


\section{Someday, on the $X$ bridge: rescue narrative}

When a Japanese male character is not metaphorically emasculated (like Ryu in Kagirinaku tōmei ni chikai burū) or absent (like Kumiko's father in Taihai shimai) in relation to the pan-pan girls, he may appear as their rescuer. Set in the immediate postwar period of 1945-1947, Kumagai Tatsuya's 2008 Itsuka X-hashi de narrates the rescuing and redemption of a pan-pan girl. Yusuke, the novel's teenage protagonist, bumps into his earlier love interest, Yoshiko, who has become a pan-pan girl. In their earlier encounter a year before, Yoshiko was dressed in simple trousers and a white blouse, her hair in pigtails; her manners were shy, her speech polite. To Yusuke's shock, however, on their second encounter she is 'dressed like a pan-pan girl from head to toe' (Kumagai 2008: 156), wears heavy make-up and shows off her cleavage, and her language is coarse. Although Yusuke has a glimpse of the old, innocent Yoshiko (for example, she buttons up her dress on noticing his gaze), she rejects his offer to provide her with a place to stay and leaves without a word. About half way though the story, Yusuke discovers that Yoshiko has become a US soldier's 'only' - that is, his exclusive lover - and he helplessly looks at them disappear, arm in arm, into the darkness. However, it turns out that the soldier has a wife and children back home, and has also selected a new pan-pan girl as his new 'only,' forcing Yoshiko back on the street.

Yusuke's love and patience eventually change Yoshiko from a promiscuous and damaged pan-pan girl to an honest and chaste woman who is committed to Yusuke. She quits pan-pan work and falls pregnant. Since motherhood is the antithesis of the panpan's non-reproductive sexuality, Yoshiko's transformation into a mother-to-be implies the taming of her dangerous sexuality and the reinstatement of the gender norm of 'good wife, good mother.' Put simply, this is a story of a Japanese man rescuing a Japanese woman from the hands of an exploitative American. Concealed in this story, however, is the unequal power relationship between the Japanese man and the Japanese woman, and that the purported rescue of the pan-pan girl amounts to Yoshiko's (re)subjection to Japanese patriarchy. The ideology of 'good wife, wise mother' characterises femininity exclusively in terms of domesticity, wifehood and motherhood; a woman's existence is defined by, and depends on, her relationship with a man and staying within the household, her sexuality thus yoked to reproduction and her husband. It is thus doubtful that a Japanese woman's subjection within Japanese patriarchy would be any better than subjection to US occupiers. 
In the rescue narrative of Itsuka X-hashi de, the evolving relationship between Yusuke and Yoshiko partially works through the humiliation of the occupied male, who then regains control by possessing a Japanese woman. This contrasts with the scene from Kagirinaku tōmei ni chikai burū, where the Japanese male is left metaphorically emasculated and powerless in front of the US soldier. It also differs from Ishikawa Jun's short story, 'Golden Legend,' in which the male protagonist, witnessing his former love interest who has become a pan-pan girl holding onto a black soldier with a healthy, strong body in stylish clothes, feels 'so shameful that he could have died' (Ishikawa 1946: 52). ${ }^{8}$ In comparison with those narratives, the rescue trope in Itsuka X-hashi de can be read as a form of therapy for a wounded Japanese male ego in the face of the sexual and military occupation by US forces.

\section{The pan-pan girls as a trope for remembering the occupation}

Sex is commonly used as a metaphor for power relations between the ruler and the ruled in colonial settings. As Sakai Naoki says, it is thus crucial to determine whether this relationship is represented metaphorically as rape or romance (Sakai 2005: 277). For example, for the US-led occupying forces, it was important that the ruler-ruled relation be represented in the format of romance. Sakai points out that this is apparent in several US films made in Japan during the 1950s, such as House of Bamboo (Fuller 1955) and Sayonara (Logan 1957). In these Orientalist interracial romances, a Japanese woman's love for an American is construed as the acceptance of US rule, thus obscuring the often violent nature of the occupation (2005: 277-78).

However, in Japanese pan-pan literature, as we have seen, neither romance nor rape provide a major interpretive framework for the US-Japanese relationship. Sex between the pan-pan girls and GIs is depicted predominantly as a commercial transaction of sorts, where women willingly take part in their own exploitation and abuse for the sake of material gain. On the whole, the pan-pan girls are portrayed simultaneously as victims (though not of rape) and willing participants (though not of romance), but never clearly one or the other. Such representations reflect the inherent ambivalence about occupied Japan. The wartime hardship under militarism meant that the occupying forces were given the status of liberators. Many Japanese welcomed the occupation, General

\footnotetext{
${ }^{8}$ This story was censored by the occupation authority because of its explicit reference to the US soldier, and did not get published until after the occupation.
} 
Douglas MacArthur and democracy, thus earning Japan the reputation as the 'best student' of US democracy. This view was to be repeated and reinforced by US policymakers who regarded the Japanese occupation as a 'successful' model for the occupation of Iraq in the early 2000s (Dower 2003). At the same time, the occupation was - and had to be - about defeat, power and foreign control. Beneath the official discourse of the Japanese acceptance and embrace of the occupation, and the changes it brought, was a deep sense of humiliation and subugation. This contradiction was clearly seen in the predicament of Japanese women in the postwar period. While the Allies liberated them by giving them voting rights, they also exploited their sexuality. ${ }^{9}$ Representations of pan-pan girls often allude to this unresolved tension between the memory of the occupation as a humiliating liberation, and the repressed memory of Japan's complicity with the occupiers.

However, as I have noted, the humiliation and shame that often frame the representations of pan-pan girls are felt predominantly by male characters. The memory of the occupation as a national trauma, as a shameful experience of disempowerment, is arguably thus constructed from the position of a male subject. On the one hand, the highly visual, sexualised and iconic pan-pan girls function as a trope for the complex interrelations between materialism, desire, victimhood and humiliation. The trope allows the occupation to be remembered as a liberation that established democracy and yet as also somehow an obscene and humiliating period in Japanese history. Inscribed on the bodies of the pan-pan girls in literature is the repressed memory of the occupation as a humiliating liberation, which problematises the dominant Japanese understanding of postwar history as a process of willing and successful Americanisation.

On the other hand, the use of the pan-pan girls as the symbolic bearers of a repressed memory of the occupation normalises chastity and closes off the pan-pans' potential to challenge the mores of Japanese patriarchy. As Yoneyama Lisa argues, it is problematic to regard Japanese women's postwar history as a story of coloured women liberated by white men, who gave them the vote and rescued them from oppression by men of colour (2003: 74). Indeed, the literary texts discussed in this essay, in part challenge such a view: men of colour have the revenge, or perhaps dominate the textual postscript.

\footnotetext{
${ }^{9}$ In the immediate postwar period, there were many cases of Japanese women being raped and assaulted. See Svoboda (2009) and Tanaka (2001).
} 
Such depictions of the pan-pan girls also indicate that for many Japanese authors the shameful acceptance and assimilation of the victor's culture can be explained in relation to feminine desire, which thus distances the national male subject from a shameful position. The male characters' pitying, despising and/or rescuing of pan-pan girls relieve the Japanese male subject of his agency and responsibility for the violence of the occupation, and leave the mores of Japanese patriarchy unquestioned and unchallenged. In so far as this kind of representation silences the pan-pan girls' voices, and subordinates them to male voices and subject positions, it also functions at times as a form of textual violence.

\section{Conclusion}

The interrelationship between gender and occupation/militarism is very much a vexed political concern in the contemporary world, and underwrites such issues as the continuing use of sexual violence in wars and occupations, the institutionalisation of prostitution around US bases, and entrenched discrimination against female soldiers. Literary texts, too, have potential relevance for how we think about these matters. In postwar Japanese literature, representations of the pan-pan girls often evoke and allude to multiple power relations: between the US and Japan; between US men and Japanese men; between Japanese men and Japanese women; as well as between middle-class and lower-class women. While such power relations are not unique to Japan in the period between 1945 and 1952, the pan-pan girls were products of the symbiosis between the Japanese government and the US Occupation at a specific moment in Japanese history. The appearance and ambivalent uses made of pan-pan girls in postwar literary texts thus sheds light on the specific construction of a Japanese national narrative anchored in the purported advances brought about by the Allied occupation.

\section{Acknowledgements}

The research for this article was supported by the University of Auckland's Grant-in-Aid in 2009. An earlier version was delivered at the 'Gender and Occupations and Interventions in the Asia-Pacific 19452009' workshop at the University of Wollongong in December 2009. I am grateful to Professor Matthew Allen, University of Wollongong, and the members of the women's writing group, Faculty of Arts, University of Auckland, for their valuable comments on the earlier drafts of this article. I would also like to thank the anonymous reviewers for their generous and thoughtful suggestions for revision. 


\section{Reference List}

Abe, A. 1980, 'Sennen,' in Umi kara no kaze. Sakuhinsha, Tokyo, 9-108.

Abe, K. 2006, Shinsemia III. Asahi bunko, Tokyo.

Arai, E. 2007, 'Kirisutokyō-kai no "panpan” gensetsu to magudara no maria,' in Senryō to sei: seisaku, jittai, hyōshō,' (ed.) Keisen jogakuen daigaku heiwa bunka kenkyūjo. Inpakuto shoppankai, Tokyo, 149-78.

Aruga, N. 2005, 'Amerika senryō-gun muke “ian-shisetsu” ni mirareru jendā, jinshu, kaikyū—on RAA,' in Taiheiyō-sekai no bunka to amerika: tabunka-shugi, dochaku, jendā, (ed.) Y. Takita. Sairyūsha, Tokyo, 77-101.

Caruth, C. 1996, Unclaimed Experience: Trauma, Narrative and History. Johns Hopkins University Press, Baltimore.

Chasono, T. 2002, 'Katari tsukusareru koto / ryōkai sarete shimau koto: pan-pan to iu hyōshō,' Joseigaku Nenpō, vol. 23, 90-107.

Dower, J. 1999, Embracing Defeat: Japan in the Aftermath of World War II. Penguin Books, London.

Dower, J. 2003, ‘A Warning from History: Don't Expect Democracy in Iraq,' Boston Review (Feb./March). Online, available: http://www.bostonreview.net/BR28.1/dower.html (Accessed 29 March 2010).

Fuller, S. (dir.) 1955, House of Bamboo, motion picture, $20^{\text {th }}$ Century Fox.

Hotta, Y. 2004, 'Kumoribi,' in Shōgen to shite no bungaku, (eds) S. Ōoka et al. Gakugei shorin, Tokyo, $283-308$

Ivy, M. 2008, ‘Trauma's Two Times: Japanese Wars and Postwars,' positions, vol. 16, no. 1, 165-88.

Kaplan, A. 2005, Trauma Culture: The Politics of Terror and Loss in Media and Literature. Rutgers University Press, New Brunswick, NJ.

Koikari, M. 1999, 'Rethinking Gender and Power in the US Occupation of Japan, 1945-1952,' Gender \& History, vol. 11, no. 2, 313-35.

Kumagai, T. 2008, Itsuka X-hashi de. Shinchōha, Tokyo.

LaCapra, D. 2002, Writing History, Writing Trauma. Johns Hopkins University Press, Baltimore.

Lamarre, T. 2008, 'Born of Trauma: Akira and Capitalist Modes of Destruction,' positions, vol. 16, no. 1, 131-56.

Lie, J. 1997, 'State as Pimp: Prostitution and the Patriarchal State in Japan in the 1940s,' The Sociological Quarterly, vol. 38, no. 2, 251-63.

Molasky, M. 1999, The American Occupation of Japan and Okinawa: Literature and Memory. Routledge, London.

Murakami, R. 1978, Kagirinaku tomei ni chikai burū. Kōdansha bunko, Tokyo.

Neal, A. 1998, National Trauma and Collective Memory. M.E. Sharpe, Armonk, NY.

Nishino, T. 2004, 'C-machi de no nōto,' in Shōgen to shite no bungaku, (eds) S. Ōoka et al. Gakugei shorin, Tokyo, 366-92.

Ishikawa, J. 1954, 'Ōgon densetsu,' in Gendai hihon bungaku zenshū, vol. 49. Chikuma shobō, Tokyo, 49-52.

Ito, Y. 1974, Sengo nihon josei-shi. Ōtsuki shoten, Tokyo.

Itoya, S. \& Ezashi, A. 1977, Sengo-shi to josei no kaihō. Gōdō shuppan, Tokyo.

Ivy, M. 2008, 'Trauma's Two Times: Japanese Wars and Postwars,' positions, vol. 16, no. 1, 165-88.

'Japan: Prostitutes' Union.' 1946, Time, 16 Sep. Online, available: http:/www.time.com/time/magazine/article/0,9171,888318,00.html (Accessed 29 March 2010).

Sakaguchi, A. Machi wa furusato, Aozora bunko. Online, available: http://www.wattpad.com/57268?p=5 (Accessed 29 March 2010).

Sakai, N. 2005, 'Eizō to jendā' in Keizoku suru shokuminchi-shugi, (eds) M. Iwasaki et al. Seitōsha, Tokyo, 276-91.

Logan, J. (dir.) 1957, Sayonara, motion picture, Warner Bros.

Shimada, M. 2005, Taihai shimai. Bunshun bunko, Tokyo.

Svoboda, T. 2009, 'U.S. Courts-Martial in Occupation Japan: Rape, Race, and Censorship,' The AsiaPacific Journal, vol. 21 (01-09). Online, available: http://www.japanfocus.org/-TereseSvoboda/3148 (Accessed 24 Aug. 2010)

Tanaka, Y. 2001, Japan's Comfort Women: Sexual Slavery and Prostitution during the World War II and the US Occupation. Routledge, London.

Yoneyama, L. 2003, 'Hihanteki feminizumu no keifu kara miru nihon senryō,' Shisō, no. 955, 60-84.

Yoshimi, S. 2007, Shinbei to hanbei. Iwanami shinsho, Tokyo. 